\title{
PENINGKATAN KEMAMPUAN SISWA DALAM MENEMUKAN POKOK- POKOK BERITA DENGAN MODEL JIGSAW DI KELAS VII E SMP NEGERI 16 KOTA JAMBI
}

\author{
Arita Sy. ${ }^{1}$ \\ Sekolah Menengah Pertama (SMP) Negeri 16 Kota Jambi \\ aritaita20@gmail.com
}

\begin{abstract}
This study aims to describe the improvement in students' ability to find news headlines by using the Jigsaw model in class VIII E of SMP Negeri 16 Jambi City, Kota Baru subdistrict, Jambi City in the academic year 2020/2021. The object of this research is students assessment which are scored based on news substance and linguistic aspects. The substance aspect consists of the ability to determine news headlines using the Jigsaw learning model. Meanwhile linguistic aspects include the ability to use news elements, namely $5 W+1 H$ in determining news headlines. The data source of this research is Class VIII E SMP Negeri 16 Kota Baru Subdistrict, Jambi City in the academic year 2010/2011. The number of the students is 41 people from the total class VIII students as many as 162 people. The results of this research showed that the jigsaw model has not been effective in improving students' ability to find news headlines. It is known from the ability of students in determining the subject matter is still low. This can be seen from the percentage results, students get a very good categorical score of only 2 people or $4.88 \%$, the good category is either 13 people or $31.70 \%$, the fair category is 18 people or $43.90 \%$ while the less category is 8 people or $19.51 \%$ as for the average score they get 57.70 and rounded up to 58. Thus the ability to determine the news headlines by students of Grade VIII E SMP Negeri 16 Jambi City District Kota Baru, Jambi City in the $2010 / 2011$ academic year is classified as less.
\end{abstract}

Keywords : Jigsaw model, improving students' ability, finding news headlines

\footnotetext{
${ }^{1}$ Guru Mata Pelajaran Bahasa Indonesia, Sekolah Menengah Pertama (SMP) Negeri 16 Kota Jambi
}

Peningkatan Kemampuan Siswa dalam Menemukan Pokok-Pokok Berita dengan Model Jigsaw di Kelas VII E SMP Negeri 16 Kota Jambi 


\section{PENDAHULUAN}

Pembelajaran bahasa Indonesia diarahkan untuk meningkatkan kemampuan peserta didik berkomunikasi menggunakan bahasa Indonesia dengan baik dan benar, baik secara lisan maupun tulisan (Puspita, Gafar dan Rofii, 2019:105). Keterampilan berbahasa di sekolah berpusat pada empat jenis keterampilan berbahasa yaitu keterampilan mendengarkan, berbicara, membaca dan menulis. Pembelajaran keterampilan berbahasa mendorong siswa pada pelatihan pemakaian bahasa sebagai alat komunikasi di masyarakat nantinya.

Pembelajaran bahasa Indonesia, khususnya pembelajaran mendengarkan diarahkan untuk meningkatkan kemampuan siswa dalam komunikasi secara lisan dan tulisan. Guru berperan aktif untuk memberi bekal kepada siswa berupa pengetahuan, kemampuan dan sikap agar siswa dapat mengakses informasi multiglobal yang berorientasi kepada keterbukaan di masa depan, sedangkan kemampuan mendengarkan seseorang tidak dapt berkembang dengan sendirinya, tetapi memerlukan bimbingan dan latihan instensif. Latihan mendengarkan di sekolah, salah satunya mendengarkan berita dari radio atau televisi untuk memperoleh informasi. Siswa harus memiliki kompetensi mendengarkan dengan baik untuk menyerapkan informasi tersebut sebab rendahnya kemampuan siswa mendengarkan sebuah berita menyebabkan rendahnya kemampuan siswa dalam menemukan informasi suatu berita untuk menemukan pokok-pokok berita.

Berdasarkan nilai ketuntasan belajar siswa khususnya pada aspek menemukan pokok-pokok berita rendah di kelas VII E semester II tahun ajaran 2010-2011 di SMP N 16 Kota Jambi, dirasakan masih untuk itu peneliti memilih kompetesi dasar ini untuk diteliti. Salah satu upaya yang dapat digunakan untuk mewujudkan pembelajaran efektif dalam mengoptimalkan hasil belajar, yakni dengan cara menggunakan model pembelajaran (Rofii, Murtadho, dan Rahmat, 2019).

Mengingat hal tersebut di atas untuk mengetahui sejauh mana kemampuan siswa kelas VII E SMP N 16 Kota Jambi dalam menemukan pokok-pokok berita dan utuk mengadakan penelitian ini maka 
peneliti menggunakan model maupun pola tindakan pembelajaran pembelajaran Jigsaw dengan tersebut. Rofii, Murtadho dan Rahmat berdasarkan bahwa materi dapat (2018) mengatakan bahwa "Model dibahas secara berkelompok, dimana siswa yang dianggap mampu difungsikan sebagai tim ahli dan dapat membantu anggota kelompok yang dirasakan kemampuannya kurang sehingga dapat meningkatkan kemampuan sacara individu.

Adapun tujuan penelitian adalah untuk mengetahui keefektifan model Jigsaw dalam meningkatkan kemampuan siswa dalam menemukan pokok-pokok berita di kelas VII E SMP N 16 Kota Jambi.

\section{Kajian Teoretik}

Menurut Trianto (2011:22) model pembelajaran yaitu suatu perencanaan atau suatu pola yang digunakan sebagai pedoman dalam merencanakan pembelajaran di kelas atau pembelajaran dalam tutorial dan untuk menentukan perangkat-perangkat pembelajaran termasuk di dalamnya buku-buku, film computer, kurikulum dan lainnya. Sementara Abidin $\quad$ (2013:117) mengemukakan bahwa model pembelajaran adalah suatu konsep yang membantu menjelaskan proses pembelajaran baik menjelaskan pola pikir pembelajaran merupakan petunjuk bagi guru merencanakan pembelajaran di kelas, mulai dari mempersiapkan perangkat pembelajaran, memilih media dan alat bantu, sampai alat evaluasi yang mengarah pada usaha mencapai tujuan pelajaran.

Sementara Tara (2018) mengatakan bahwa pembelajaran menentukan pokok pokok teks berita diberikan dengan tujuan agar siswa mampu menganalisis teks berita menggunakan unsur $5 \mathrm{~W}+1 \mathrm{H}$ (apa, di mana, kapan, siapa, mengapa, dan bagaimana) secara lengkap, dan mampu menulis teks berita dengan ejaan dan tanda baca secara tepat. Hal ini sesuai dengan pendapat Chaer (2010: 17) yang menjelaskan bahwa berita harus mengungkapkan unsur $5 \mathrm{~W}$ dan $1 \mathrm{H}$, yang mencakup what (apa yang terjadi), who (siapayang terlibat dalam kejadian), why (mengapa kejadian itu terjadi), where (di mana kejadian itu terjadi), when (kapan terjadinya), dan how (bagaimana kejadiannya).

Model pembelajaran jigsaw adalah sebuah model belajar kooperatif 
yang menitik beratkan kepada kerja kelompok siswa dalam bentuk kelompok kecil, seperti yang diungkapkan Lie (1993: 73), bahwa pembelajaran kooperatif model jigsaw ini merupakan model belajar kooperatif dengan cara siswa belajar dalam kelompok kecil yang terdiri atas empat sampai dengan enam orang secara heterogen dan siswa bekerja sama salaing ketergantungan positif dan bertanggung jawab secara mandiri.

Dalam model pembelajaran jigsaw ini siswa memiliki banyak kesempatan untuk mengemukanakan pendapat, dan mengelolah informasi yang didapat dan dapat meningkatkan keterampilan berkomunikasi, anggota kelompok bertanggung jawab atas keberhasilan kelompoknya dan ketuntasan bagian materi yang dipelajari, dan dapat menyampaikan kepada kelompoknya (Rusman, 2008.203).

Selanjutnya menurut Rusman (2008: 205) model pembelajaran jigsaw ini dikenal juga dengan kooperatif para ahli. Karena anggota setiap kelompok dihadapkan pada permasalahan yang berbeda. Namun, permasalahan yang dihadapi setiap kelompok sama, kita sebut sebagai tim ahli yang bertugas membahas permasalahan yang dihadapi.
Selanjutnya, hasil pembahasan itu di bawa keepada kelompok asal dan disampaikan kepada anggota kelompoknya.

Adapun kegiatan yang dilakukan pada model pembelajaran kooperatif jigsaw sebagai berikut:

1. Membaca untuk menggali informasi. Siswa memperoleh topik-topik permasalahan untuk di baca sehingga mendapatkan informasi dari permasalahan tersebut.

2. Diskusi kelompok ahli. Siswa yang telah mendapatka topik permasalahan yang sama bertemu dalam satu kelompok atau disebut dengan kelompok ahli untuk membicarakan topik permasalahan tersebut.

3. Laporan kelompok. Kelompok ahli kembali ke kelompok asal dan menjelaskan hasil yang didapat dari diskusi tim ahli.

4. Kuis dilakukan mencakup semua topik permasalahan yang dibicarakan.

5. Perhitungan skor kelompok dan menetukan penghargaan kelompok.

Menurut Suharma,dkk (2002) pokok berita adalah masalah utama yang dibahas dalam sebuah berita. Pada umumnya pokok berita dari radio/ televisi disampaikan di awal berita. 
Selajutnya Pardjimin (2005) menjelaskan bahwa tehnik membaca berita dapat dilakukan dengan langkah-langkah berikut.

1. Membaca dengan cermat dan teliti.

2. Memberi tanda pada kata-kata kunci atau hal yang penting pada teks.

3. Berkonbsentrasi dalam membaca.

Agus (2009; 22) mengatakan bahwa kerja sama kelompok adalah kumpulan individu yang mempunyai hubungan tertentu yang saling ketergantungan dalam ukuran yang bermakna.

\section{METODE PENELITIAN}

Penelitian ini merupakan penelitian tindakan kelas (PTK) yang pertamakali dikenalkan oleh ahli psikologi sosial Amerika yang bernama Kurt Lewin pada tahun 1946. Penelitian tindakan kelas adalah penelitian yang mengacu kepada tindakan yang dapat dilakukan guru secara langsung dalam usaha memperbaiki proses belajar mengajar.

Penelitian Tindakan kelas ini dilaksanakan di kelas VII E SMP N 16 Kota Jambi pada semester II tahun pelajaran 2010-2011. Adapaun subjek penelitian ini berjumlah 41 orang siswa yang terdiri atas 21 siswa laki-laki dan 20 orang siswa perempuan. Penelitian ini dilaksanakan pada bulan Januari 2020 dengan waktu sesuai dengan jadwal mengajar di kelas tesebut. Adapun penelitian ini melibatkan beberapa observer yaitu rekan sejawat MGMP BERMUTU Bahasa Indonesia Rayon III Kota Jambi sebanyak 20 orang dengan pelaksanaan open class.

Adapun

langkah-langkah penelitian yang dilakukan sebagai berikut.

1. Penyususnan RPP dengan KD Menemukan pokok-pokok berita dengan scenario pembelajaran model Jigsaw.

2. Rekaman berita melalui internet seputar gempa mentawai dan meletusnya gunung merapi dengan durasi berita $8-10$ menit

3. Mengelompokkan siswa sebanyak 6 kelompok sesuai dengann unsurunsur berita $5 \mathrm{~W}+1 \mathrm{H}$

Analisis data dengan melaksanakan tindakan yang terdiri dari 2 siklus. Pada siklus I siswa menemukan pokok - pokok berita sacara untuh dan pada siklus II siswa menemukan pokok -pokok berita dengan menggunakan model jigsaw. 


\section{HASIL DAN PEMBAHASAN}

Data diperoleh dengan tehnik observasi, test, pengamatan lapangan dan pengumpulan data. Observasi dilakukan bersamaan dengan perbaikan pembelajaran apa yang terjadi dalam pembelajaran ketika berinteraksi dengan sumber-sumber belajar, sedangkan pengamatan dilakukan dengan mengamati proses pembelajaran dan dokumen hasil belajar melalui test formatif nilai harian. Kegiatan ini dibantu teman sejawat yang tergabung dalam MGMP BERMUTU Rayon III Kota Jambi dalam mengamati proses pembelajaran. Tehnik analisis data bertujuan untuk mengukur tingkat kemampuan siswa menemukan pokokpokok berita melalui kerjasama kelmpok sirklus pertama dan sirklus ke dua. Data pada penelitian ini berupa data kuantitatif dengan cara membandingkan nilai awal, siklus I dengan siklus II.

Pembelajaran menemukan pokok-pokok berita dengan menggunaka model jigsaw secara sistematik sebagai berikut.
1. Siswa berhitung dari satu sampai enam sehingga terbentuk 6 kelompok dari 36 orang siswa

2. Diperdengarkan berita seputar gempa bumi di Mentawai.

3. Secara individu siswa menemukan pokok berita sesuai dengan nomor yang diberikan padanya.

4. Peneliti membentuk kelompok siswa satu kelompok terdiri dari 6 orang sesuai dengan unsur-unsur berita 5 $\mathrm{W}+1 \mathrm{H}($ ASKAMEDIBA) .

5. Sebagai ketua kelompok yaitu siswa Sebagai team ahli.

6. Secara kelompok siswa menyamakan apersepsi

7. Siswa dikembalikan kepada kelompok asal (kelompok utuh) untuk berdiskusi menemukan pokok-pokok berita secara utuh

8. Kelompok yang selesai paling awal membacakan hasil diskusi.

9. Guru dan siswa mengadakan refleksi pembelajaran.

Hasil penelitian ini menujukkan bahwa model jigsaw belum efektifmeningkatkan kemampuan siswa dalam menemukan pokok-pokok berita. Hal tersebut diketahui dari kemampuan siswa dalam menentukan pokok-pokok berita tersebut masih rendah. Hal ini 
terlihat dari hasil persentase, siswa memperoleh nilai katagori sangat baik hanya 2 orang atau $4,88 \%$, katagori baik 13 orang atau $31,70 \%$ katagori cukup 18 orang atau $43,90 \%$ katagori kurang 8 orang atau $19,51 \%$ adapun skor rata - rata yang diperoleh mereka yaitu 57,70 dan dibulatkan menjadi 58. Dengan demikian kemampuan menentukan pokok - pokok berita oleh siswa Kelas VIII E SMP Negeri 16 Kota Jambi Kecamatan Kota Baru, Kota Jambi tahun pelajaran 2010/ 2011 tergolong kurang/ rendah.

\section{SIMPULAN}

Berdasarkan hasil dari perkembangan penelitian tindakan ini dapat disimpulkan sebagai berikut.

1. Model pembelajaran jigsaw menjadikan siswa ikut terlibat aktif dalam pembelajaran.

2. Model pembelajaran jigsaw merupakan model pembelajaran yang menyenangkan bagi siswa. Hal tersebut terlihat pada proses pembelajaran siswa lebih antusias dalam mengikuti pelajaran dan dalam proses pembelajaran tidak didominasi oleh guru.

3. Walaupun demikian, dengan aktif dan antusiasya siswa pada proses pembelajaran, kemampuan siswa menemukan pokok-pokok berita dari radio dan televisi belum dapat ditingkatkan secara optimal.

\section{Saran}

Beberapa hal yang dapat disarankan dari penelitian ini adalah sebagai berikut.

1. Model pembelajaran jigsaw dalam penelitian ini dapat dijadikan alternatif model pembelajaran untuk kompetensi dasar menemukan pokok-pokok berita melalui radio/televisi.

2. Penelitian tindakan kelas ini, masih terdapat banyak kekurangan, jadi dapat ditindaklanjuti oleh guru mata pelajran bahasa Indonesia lainnya.

\section{DAFTAR PUSTAKA}

Abidin, Yunus. (2013). Desain Sistem Pembelajaran dalam Konteks Kurikulum. Bandung: Refika Aditama.

Chaer, A. (2010). Bahasa Jurnalistik. Jakarta: Rineka Cipta. Pardjimin. (2005). Bahasa dan Sastra Indonesia Kelas VIII. Bogor: PT Ghalia Indonesia. 
Puspita, Tara., Gafar, Abdul., Rofii, Afif.

(2019) Pengaruh Penggunaan

Model Pembelajaran Think Pair

Share terhadap Keterampilan

Menulis Surat Pribadi Siswa

Kelas VII SMP Negeri 5 Kota

Jambi. Aksara: Jurnal Ilmiah

Pendidikan Bahasa dan Sastra

Indonesia Vol. 3 No. 1 April 2019.

Rofii, Afif., Fathiaty, Murtadho., Rahmat, Aceng. (2019 A). Needs Analysis: A Learning Model for

CTL-Based Academic Writing.

Proceedings of the Eleventh

Conference on Applied

Linguistics (conaplin 2018).

Rofii, Afif., Murtadho, Fathiaty., Rahmat, Aceng. (2019 B). The Perception of Lecturers and Students on Learning Model of Contextual-Based Academic Writing. Proceeding First

International Conference on

Advances in Education,

Humanities, and Language.

Malang: EAI.

Rusman (2018). Model- Model

Pembelajaran. Jakarta: Rajawali

Pers. PT Rajagrafindo Persada.
Suharma ,dkk. (2002) Bahasa dan Sastra Indonesia kelas VIII. Surakarta: Pusat Perbukuan Depertemen Pendidikan Nasional

Suprijono, Agus. (2009). Cooperative Learning. $\quad$ Yogyakarta: Perpustakaan Sekolah.

Tara, Firman. (2018). Perbandingan Penggunaan Model Pembelajaran Kooperatif Tipe Stad dengan Model Pembelajaran Langsung Terhadap Kemampuan Menulis Teks Berita Siswa Kelas VIII Smp Negeri 24 Jambi. Jurnal Ilmiah Dikdaya. Vol 18. Nomor 2 tahun 2018

Trianto, (2011). Mendesain Model Pembelajaran Inovatif-Progresif. Jakarta: Kencana Prenada Media Group. 